INTERNATIONAL JOURNAL OF LEGAL INFORMATION

\author{
The Official Publication of the \\ International Association of Law Libraries
}

IJLI Vol. 13

June-August 1985

Nos. 3-4

CONTENTS

ARTICLES

Marriage and Marital Property under the New Greek Family Law

by Theresa Papademetriou....................... 1

Prevention of Child Abuse in Switzerland: Statutes and Court Decisions

by Petru Buzescu .............................. 41

NOTES AND COMMENTS

The 26th Annual Meeting of the IALL, July 21-26, 1985 ........ 45

The 51st IFLA Council and General Conference, IALL

Round Table............................... 45

Declaration on Transborder Data Flows, adopted by the

OECD Member States ......................... 46

International Legal Materials Cumulative Index,

1970-1979 (Volumes IX-XVIII) $\ldots \ldots \ldots \ldots \ldots \ldots \ldots \ldots \ldots \ldots . \ldots \ldots$

BIBLIOGRAPHY

Soviet Laws Translated into the English Language:

A Bibliographic List Through December 31, 1984

Compiled by Jeanna A. Brannon

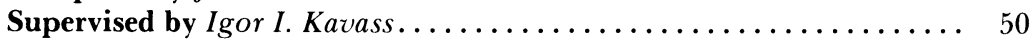

PERIODICAL REVIEWS

New Periodicals

by Timothy Kearley......................... 84

Santa Clara Computer and High Technology Law Journal ......... 84

Droit de l'Informatique ........................... 84

Computer Law ................................ 85

Journal de Droit des Affairs Internationales . . . . . . . . . . . . . 85

Corporate Counsel's International Adviser . . . . . . . . . . . . . . 85

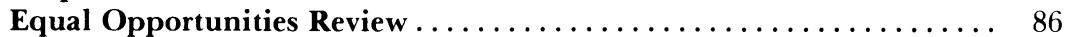

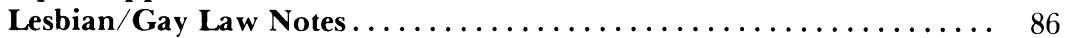

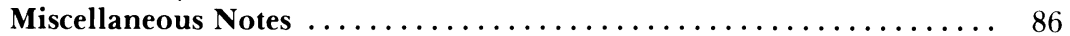




\section{INTERNATIONAL DOCUMENTATION}

by Robert W. Schaaf

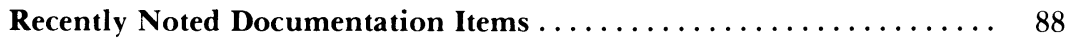

Compilation of UN Treaties on Outer Space $\ldots \ldots \ldots \ldots \ldots \ldots \ldots \ldots \quad 88$

Convention on the Physical Protection of Nuclear

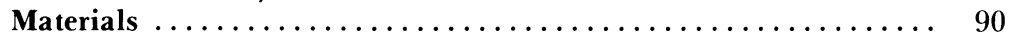

Notes and References........................... 93

THE INTERNATIONAL BOOKSHELF BOOK REVIEWS

Kaiser: Prison Systems and Correctional Laws: Europe,

The United States, and Japan

by Frankie Fook-Lun Leung.

van Dijk and van Hoof: Theory and Practice of the

European Convention on Human Rights

by Marie-Louise H. Bernal.

Kurowski, ed.: General Principles of Law of the Polish

People's Republic

Song, ed.: Introduction to the Law and Legal System of Korea

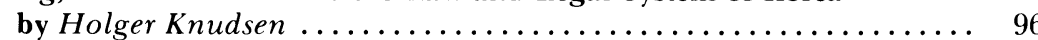

Stikeman and Elliott, eds.: Doing Business in Canada

by Stephan F. Clarke ........................... 98

Vincze: The International Payments and Monetary System

in the Integration of the Socialist Countries

by Ivan Sipkov . . . . . . . . . . . . . . . . . . . . . . . . . . . . . 99

The Guide to American Law: Everyone's Legal Encyclopedia

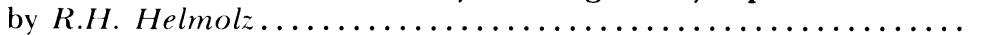

Chandler, Enslen, and Renstrom: The Constitutional Law

Dictionary

by George E. Glos ............................. 102

Hawk, ed.: Antitrust and Trade Policies of the European

Economic Community

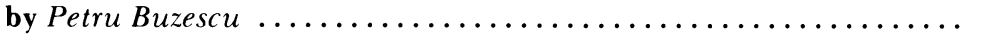

Hanami: Labour Law and Industrial Relations in Japan

by Frankie Fook-Lun Leung ......................... 105

McDaniel and Surrey, eds.: International Aspects of Tax

Expenditures: A Comparative Study

by George E. Glos ........................... 106

Walter, Muller-Zarth and Garbas, eds.: Union List of Legal

Serials in Selected Libraries of the F.R. of Germany

by Dieter Giesen ............................ 107

Margairza and Merkli: The Taxation of Corporations in

Switzerland

by Miklos K. Radvanyi ......................... 108 
Macalister-Smith: International Humanitarian Assistance.

Disaster Relief Actions in International Law and Organization

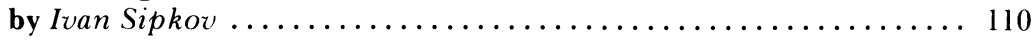

Heller, Löber, Bahn, Huber, and Horwath: Austrian Law: Legal, Accounting, and Tax Aspects of Business in Austria

by Edith Palmer

David: Arbitration in International Trade

by Claire Germain ........................... 113

BOOKS RECEIVED AND NOTED

I. Periodicals and Serials ....................... 115

II. Bibliographies, Dictionaries, Reference Works ........... 115

III. Commonwealth and Common Law ................. 116

IV. Comparative Law ........................... 117

V. European Communities..................... 117

VI. International Private and Public Law ................. 117

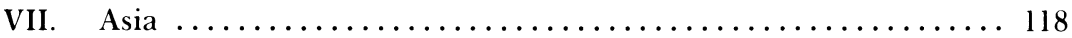

VIII. Eastern Europe, USSR ......................... 118

IX. Western Europe $\ldots \ldots \ldots \ldots \ldots \ldots \ldots \ldots \ldots \ldots \ldots \ldots \ldots \ldots \ldots$ 


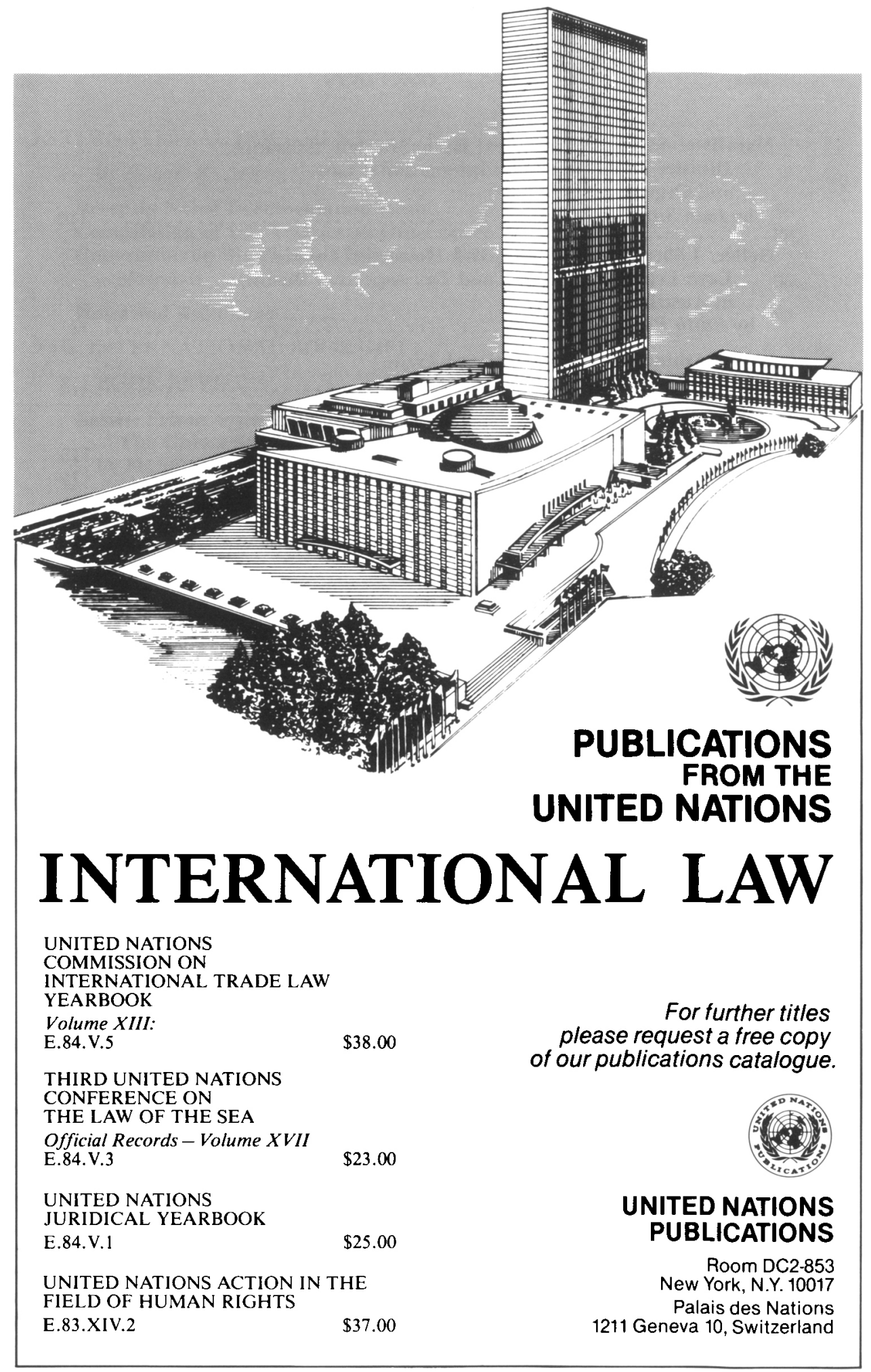




\section{Editor-in-Chief: IVAN SIPKOV*}

\section{EDITORIAL POLICY:}

The International Journal of Legal Information invites for publication the submission of manuscripts for articles, bibliographies, notes, book reviews, and documents concerning law and law-related information.

The views expressed in the articles, editorial comments, book reviews and other contributions which appear in IJLI are the responsibility of the individual authors/ contributors and do not imply the endorsement of the Editorial Board.

\section{MANUSCRIPT INFORMATION:}

All materials intended for inclusion in any of the sections of the IJLI should be sent directly to the Editorial Office.

\section{SUBSCRIPTION INFORMATION:}

Subscription rates are included in the IALL MEMBERSHIP.

Rates per subscription-individuals $\$ 40.00$ (U.S.) per year institutions $\$ 60.00$ (U.S.) per year

Single copies: $\$ 15.00$ (U.S.)

Checks should be made payable to the IALL and sent to the Business Address of the Association.

Subscriptions, change of address notices, single copy requests, claims, and advertisements should be addressed to the Business Address of the Association.

Editorial Office:

4917 Butterworth Pl., N.W.

Washington, D.C. 20016 U.S.A.
Business Address:

P. O. Box 5709

Washington, D.C. 20016-1309 U.S.A.

Law Library of Congress, Washington, D.C. U.S.A.

Issued February/April, June/August, and October/December.

Copyright $\odot 1985$ by International Association of Law Libraries.

Library of Congress No. 78-81409, ISSN 0731-1265. Printed in the United States.

*Dr. Ivan Sipkov, Chief, European Law Division, Library of Congress, Washington, D.C., U.S.A. 
Pursuant to the 1983 elections the IALL Officers and Members of the Board of Directors for the term of office from July 1, 1983 through June 30, 1986, are the following persons:

\section{OFFICERS:}

\section{President:}

KLAUS MENZINGER

University of Freiburg

Federal Republic of Germany

\section{First Vice-President:} JOHN RODWELL

Macquarie University

Australia

\section{Second Vice-President: \\ MURIEL ANDERSON \\ Institute of Advanced \\ Legal Studies \\ England \\ Secretary: \\ JOACHIM SCHWIETZKE \\ Max Planck Institute \\ Heidelberg \\ Federal Republic of Germany}

\section{Treasurer:}

GERT VLASMAN

Katholieke Hogschool

The Netherlands
MEMBERS OF THE BOARD:

DAVID COMBE

Tulane University

U.S.A.

IGOR I. KAVASS (ex officio)

Vanderbilt University

U.S.A.

ARNO LIIVAK

Rutgers University

U.S.A.

LYNN POLLACK

Supreme Court of New South Wales Australia

MICHAEL RENSHAWE

McGill University

Canada

IVAN SIPKOV

Law Library of Congress

U.S.A.

ADOLF SPRUDZS

The University of Chicago

U.S.A.

YOSHIRO TSUNO

University of Tokyo

Japan

The International Association of Law Libraries was organized in 1959 to promote on a cooperative, non-profit and fraternal basis the work of individuals, libraries, and other institutions concerned with the acquisition, bibliographic control and shared exchange of law-related information on a multi-national basis. 